\title{
Research on the Influence of Inclusive Leadership Style on Employment Relationship Climate and Employee Proactive Behavior
}

\author{
Bakri Hasanuddin ${ }^{1}$, Syahir Natsir ${ }^{2}$, Harnida W. Adda ${ }^{3}$, Yobert Kornelius ${ }^{4}$, Niluh Putu Evvy Rossanty, \\ Mustainah $\mathbf{M}^{6}$ \\ 1, 2, 3, 4, 5 Business and Economics Faculty, Tadulako University \\ ${ }^{6}$ Politics and Social Science Faculty, Tadulako University
}

\begin{abstract}
Employee job satisfaction is important to get the attention of every leader of the organization. This is because satisfied employees can be expected to produce fast, careful and accurate work. On the other hand, dissatisfied employees often take the form of indiscipline, unwillingness to take initiative and innovate. In the end, the resulting product/service is often not as expected. In this study, leadership style is an independent variable which includes; directive leadership style; participative; supportive. Job satisfaction as the dependent variable and work climate as an intervening variable. This study aims to analyze leadership styles that can increase job satisfaction and verify that work climate variables can mediate these effects. To achieve this goal, this study uses a quantitative approach with Tadulako University employees as respondents who filled out a questionnaire, which was circulated via google form, obtained as many as 71 respondents. The data analysis technique used is Partial Least Square (PLS). The results of this study indicate that the work climate can mediate the influence of leadership style on job satisfaction, and then find a leadership style that has a positive influence on employee job satisfaction through the work climate, namely, participative and supportive leadership styles.
\end{abstract}

Keywords: Leadership style, directive, participative, supportive, work climate, job satisfaction

\section{Intorduction}

Employees have a strategic role in supporting and facilitating the implementation of organizational activities. They are expected to provide satisfactory service to everyone associated with the organization they work for. One of the public organizations that is interesting to conduct research on employee job satisfaction is a higher education organization, namely Tadulako University. In this regard, employees provide services to university/faculty leaders, lecturers, students and the general public who need university services. This study is interesting because they are always required to provide satisfactory service, while on the other hand there has never been a study on the job satisfaction they feel in carrying out their routines in the office.

Job satisfaction is the extent to which a person is happy or satisfied with his/her job (Bushra., Usman., Naveed, 2011). Job satisfaction is influenced by the organization's work climate, a conducive work climate encourages every employee involved in the organization to always give their best performance for the organization. The work climate has an influence in determining the behavior and attitudes of employees. The work climate is important because it can create job satisfaction, which in turn affects work efficiency. Research on work climate affecting job satisfaction has been carried out by many people, among others (Treputtharata\&Tayiam, 2014), the results of the research show that the overall school climate affects the job satisfaction of teachers at a high level. Organizational climate that affects the job satisfaction of teachers, among others, is ongoing leadership.

It is very important for organizational leaders to pay attention to employee job satisfaction. Satisfied employees are expected to produce fast, careful and accurate work in providing the necessary data and information. On the other hand, dissatisfied employees often take the form of indiscipline, unwillingness to take initiative and innovate. In the end, the resulting administrative services are often not as expected.

The results of recent decades of research on leadership show that successful leaders are those who are able to adapt their leadership style to the needs of the situation. According to (Blanchard, 2007) leadership styles represent different combinations of directive and supportive leader behavior, which can be chosen for any situation. Directive behavior emphasizes more on structure, control, and supervision. While supportive behavior shows a leader engages in twoway communication, listens, provides support and encouragement, facilitates interaction, and involves employees in decision making.

The concept of leadership style proposed by Blanchard is very interesting to study with the aim of finding the right leadership style, which provides employee job satisfaction.

\section{Literature Review}

Although salaries and incentives that are monetary in nature provide job satisfaction to employees, they will not last long if it is not accompanied by a non-monetary atmosphere, which can maintain the level of job satisfaction from time to time, namely, the work climate and leadership style in the organization that meets theexpectations of employees. The success of an organization depends on its members being satisfied and appreciated for their work (Javed et al., 2014). The results of the study (Imran, et al, 2012) show that employee performance is positively and significantly related to the work environment and leadership. 
Work climate and leadership style of an organization are factors that influence employee attitudes towards their work, these two factors can be observed by observing the implementation of open system management, human relations that are ongoing in the organization. In this regard, it is important for leaders to maintain a positive work environment to maximize and enhance the efforts of their employees to achieve organizational effectiveness (Holloway, 2012). The results of the study (Gul et al., 2015) show that open systems and human relations as part of the work climate of an organization have a very strong influence on job satisfaction.

Work climate is a very broad concept that consists of many dimensions. It can be assessed based on employees' perceptions of various aspects of work life that develop from daily work experience, when dealing with organizational work systems, policies, targets and objectives, facilities and infrastructure, awards, management activities, and others. According to Flora (2019), employee behavior is influenced by the work climate available to them. This work climate if ethical can shape the ethics of individuals and employees as a whole in the organization. Arora et al. (2010) define climate as a set of specific attributes that can be induced by an organization in dealing with its members and their environment. The concept of organizational climate captures workers' perceptions of workplace features that are psychologically strong or influential, for example; whether workers have autonomy; pride in their work; good working relationship with other workers including their superiors; and many other working conditions. According to (Rahimic, 2013) climate significantly affects organizational and psychological communication processes, problem solving, learning, motivation, organizational efficiency and productivity, as well as innovation and job satisfaction. Therefore, climate becomes the focus of organizational experts, especially as more and more empirical data proves that a good organizational climate increases productivity and efficiency as well as increases employee satisfaction. According to (Qaiser, 2015) organizational climate as a company climate is a process of measuring organizational culture, so before explaining about organizational climate it is necessary to explain organizational culture. Organizational culture is the set of values, assumptions and beliefs that govern how people act in organizations.

The work climate consists of many dimensions that can be determined by the researcher himself. Work climate is seen as a situation, human relations including involvement in decision making, interesting and challenging tasks, attractive remuneration, career opportunities, and an overall safe work environment. Such a work climate is strongly influenced by the ongoing leadership style.

Thre leadership style according to Omolayo (2007) is a pattern of behavior carried out by leaders when dealing with employees. Leader effectiveness is the extent to which a leader continuously leads and directs his followers towards agreed-upon goals set by the whole group.

In general, leadership can be defined as the way or style of a person in leading and influencing others to achieve the goals that have been set. A leader is someone who is entrusted with being the chairman or head of an organization. A leader must be able to integrate and encourage the passion of his subordinates to achieve maximum organizational performance. Leaders have the ability to select, equip, train, and influence followers who have diverse talents, abilities, and skills towards the achievement of the mission and goals of the organization.

Blanchard (2007) suggests four leadership styles that represent different combinations of directive and supportive leader behavior, which can be chosen for any situation. Directive behavior indicates the extent to which a leader engages in one-way communication; detailing employee roles and telling employees what to do, where to do it, when to do it, and how to do it, and closely monitoring performance. Three words are used to define directive behavior, namely, structure, control, and supervision. Supportive behavior indicates a leader engages in two-way communication, listens, provides support and encouragement, facilitates interaction, and involves employees in decision making. Three words can be used to define supportive behavior namely, praise, listen, and facilitate. The combination of highly directive behavior is called directing. The directive leader tells subordinates what, how, when, and where to perform various tasks. The behavior of leaders with high directive and high support is referred to as coaching leadership style. In this style the leader still provides a lot of direction, but he or she also tries to hear how employees feel about decisions and their ideas and suggestions. The behavior of leaders with high supportiveness and low directives is referred to as a supportive leadership style. Low supportive and low directive leader behavior is referred to as delegating leadership style. In this style employees are allowed greater autonomy because they have the competence and confidence to complete tasks on their own. In this case the role of the leader is to provide recognition and actively listen and facilitate problem solving and decision making by employees.

According to Perna (2016) leadership style needs to be adapted to the situation in this case, situational leadership is useful for educating leaders about how to grow and communicate with their followers in important situations. Although situational leadership primarily looks at situational leadership styles, it is useful in understanding leaders' communication patterns. Leaders who use and have knowledge of situational leadership may be able to empower, transform, and inspire followers with other leadership styles, such as participati leadership styles.

\section{Research Hypothesis}

1) The directive leadership style has a significant effect on the work climate.

2) The participative leadership style has a significant effect on the work climate.

3) Supportive leadership style has a significant effect on the work climate.

4) Work climate has a significant effect on job satisfaction and mediates the indirect effect of leadership style (directive, supportive, participative) on job satisfaction. 


\section{Research Method}

This study uses data collection techniques through distributed questionnaires, via google forms sent via social media, namely whatsapp to all employees who can be contacted via cell phones, of which 71 respondents were obtained.

Table 1: Variables in the model

\begin{tabular}{|l|l|}
\hline A. Exogenous latent variables & Number of indicators \\
\hline 1. Directive leadership style & 6 indicators $\left(\mathrm{X}_{1.1}-\mathrm{X}_{1.6}\right)$ \\
2. Participative leadership style & 6 indicators $\left(\mathrm{X}_{2.1}-\mathrm{X}_{2.6}\right)$ \\
3. Supportive leadership style & 6 indicators $\left(\mathrm{X}_{3.1}-\mathrm{X}_{3.6}\right)$ \\
\hline B. Endegenous latent variables & Number of indicators \\
4. Work climate & 9 indicators $(\mathrm{Y} .1-\mathrm{Y} .9)$ \\
5. Job satisfaction & 12 indicators $\left(\mathrm{Z} .1-\mathrm{Z} .1_{4}\right)$ \\
\hline
\end{tabular}

\section{Data Analysis Techniques}

The data analysis technique used in this study is PLS (Partial Least Square), using the SmartPLS 3.0 program. Analysis with this approach is a quantitative analysis. In accordance with the conceptual framework that has been developed based on the results of theoretical studies and hypotheses to be tested. PLS is able to test the formative and reflective models by measuring the Likert scale indicators used in this study. PLS is a powerful analytical method because it does not require many assumptions, can be applied to all data scales, namely nominal, ordinal, interval, and ratio (distribution free), and the sample size does not have to be large. Steps taken:

\section{1) Measurement Model or Outer Model}

The outer model is also known as the outer relation or measurement model which defines how each indicator block relates to its latent variables. This model is used to determine the validity and reliability of the linking indicators with latent variables. The equation for the outer model (Yamin\&Kurniawan, 2009: 214) is:

$\mathrm{x}=\Pi \mathrm{x} \xi+\varepsilon \mathrm{x}$

$\mathrm{y}=\Pi y \eta+\varepsilon y$

Notes:

$\mathrm{x}$ : matrix of manifest variables related to exogenous latent construct $\xi$

$\mathrm{y}$ : matrix of manifest variables related to endogenous latent construct $\eta$

Пx dan Пy: coefficient matrix (loading matrix)

Ex dan ey: residual model outer matrix

The indicators in this study are reflective indicators because the latent variables affect the indicators. For this purpose, the following measurement methods are used:

\section{a) Validity Test}

\section{- Convergent Validity}

Convergent validity measures the magnitude of the correlation between the construct and the latent variable where the theoretical constructs must relate to each other. To measure the validity of the indicator, the loading factor value $>0.7$. Nevertheless, the standardized loading factor value, above 0.6 is acceptable (Hussein, 2018: 22), while below 0.6 is excluded from the model. The measurement of the validity of the latent variable uses the average variance extracted (AVE) value $>0.5$ to say that the data is valid (Ghozali, 2014: 40), if something is invalid, then the indicator must be reduced and reconstructed.

\section{- Discriminant Validity}

Discriminant validity is done by calculating the cross loading value in each indicator of the latent variable and comparing the AVE root value with the correlation value between latent variables. The AVE root value must be greater than the correlation between latent variables. The results of the discriminant validity test are if the cross loading value in each indicator is the largest value for the parent latent variable, then the data is valid.

\section{b) ReliabilityTest}

\section{- Composite Reliability}

This value indicates internal consistency, namely a high composite reliability value indicates the consistency value of each indicator in measuring the construct. Expected CR value > 0.7 (Ghozali, 2014: 40).

\section{- Cronbach's Alpha}

The reliability test on the PLS was strengthened by the presence of Cronbach alpha where the consistency of each answer was tested. Cronbach's alpha is said to be good if 0.5 (Ghozali, 2014: 76).

\section{c) Structural Model or Inner Model}

The inner model is also called the inner relation, structural model, or substantive theory. The inner model describes the relationship between latent variables based on substantive theory (Ghozali, 2014: 37). The equation of the inner model is as follows:

$\eta=\eta \beta+\xi \Gamma+\zeta$

Notes:

$\eta$ : endogenous latent construct matrix

$\xi$ : Exogenous laten construct matrix

$\beta$ : coefficient matrix of endogenous variables

$\Gamma$ : exogenous variable matrix coefficient

$\zeta$ : inner model residual matrix

The structural model was evaluated using R-Square for each dependent latent variable and the significance of the coefficients of the structural path parameters. The assessment of the model with PLS begins by looking at the $\mathrm{R}$-Square. The interpretation is the same as the interpretation in the regression. Changes in the value of R-Square can be used to assess the effect of certain independent latent variables on the dependent latent variable whether it has a substantive effect. The higher the R-Square value, the higher the percentage of variance of the endogenous variables influenced by the exogenous variables.

\section{d) Constructing a Path Diagram}

Research hypotheses are described or constructed into path diagrams using SmartPLS 3.0.

Convert Path Diagram to System of Equations 


\section{- Inner Model}

The Inner Model determines the specification of the relationship between one latent construct and another latent construct.

\section{- Outer Model}

The Outer Model specifies the relationship between the latent construct and its indicators.

\section{e) Resampling Bootstrapping}

Resampling using the bootstrapping method needs to be carried out on analyzes using PLS to ensure the resulting value, because PLS does not require a normal distribution. A hypothesis can be accepted or should be rejected statistically can be calculated through the level of significance. The level of significance used in this study is $5 \%$. If the chosen significance level is $5 \%$, the significance level or confidence level is 0.05 to reject a hypothesis. In this study, the probability of making the wrong decision is $5 \%$ and the probability of making the right decision is $95 \%$. The following is used as the basis for decision making, namely: p-value $\leq 0,05$, then the hypothesis is accepted. $\mathrm{p}$-value $>0,05$, then the hypothesis is rejected.

Description: p-value is a probability value (probability value or opportunity value) or a value that indicates the probability of a data being generalized to the population, namely the wrong decision is $5 \%$ and the probability of making the right decision is $95 \%$.

At a significance level of 0.05 , the hypothesis will be supported on condition that the $\mathrm{t}$-value exceeds the critical value, which is 1.96 .

\section{f) Testing Moderating Variable}

The next test is to test the moderating variable. The moderating variable in this study is the work climate, namely the influence of work climate on the relationship between leadership style (directive, partisipatif, supportive,) and job satisfaction.

\section{2) PLS Analysis Results}

PLS analysis that was run using the SmartPLS version 3.0 software was carried out in three stages, namely, measuring indicators or outer models, testing structural models or inner models and testing hypotheses using Bootstrapping (Model Significance Test).

\section{a) Validity Test}

The validity test aims to evaluate convergent validity, namely, to determine the degree of conformity between the attributes of the measuring instrument's measurement results and the theoretical concepts that explain the existence of the attributes of these variables. Convergent Validity of the measurement model with reflexive indicators is assessed based on the correlation between item scores/component scores which are estimated with PLS software. Individual reflexive measures are said to be high if they correlate more than 0.7 with the construct being measured. Nevertheless, the standardized loading factor value, above 0.6 is acceptable (Hussein 2018: 22), while below 0.6 is excluded from the model.
Convergent validity dapat ketahui dari nilai outer loading masing-masing indikator variabel. Indikator dikatakan valid jika memiliki nilai di atas 0,6 . Jika nilai outer loading $<0,6$ maka harus diproses kembali sampai memenuhi convergent validity.

After modifying the model, the indicators that are eliminated are indicators X1.1 and X1.2, which are indicators of the directive leadership style variable. For the participatory leadership style variable, it appears that all the indicators meet the convergent validity requirements, as well as the supportive leadership style variable. As for the work climate variable, there is one indicator, namely, Y.3 which does not meet the convergent validity requirements. Likewise for the job satisfaction variable, there is one indicator that does not meet the requirements, namely Z.1.

After adjustment, the outer loading value is obtained as the final stage of the calculation process to show the convergent validity of each indicator on each variable in this study.

\section{b) Evaluating Discriminant Validity}

Discriminant validity measures the correlation between item scores or component scores. Discriminant validity is carried out to ensure that each concept of each latent variable is different from other variables. The model has good discriminant validity if each loading value of each indicator of a latent variable has the largest loading value compared to other loading values for other latent variables.

To assess discriminant validity, it is done by comparing the square root of average variance extracted (AVE) for each variable with the correlation value between the variables. The AVE value is used to measure the amount of variation that can be captured from the construct compared to variations caused by measurement errors.

The measurement of the validity of the latent variable uses the average variance extracted (AVE) value $>0.5$ to say that the data is valid, if any are invalid, the indicators must be reduced and reconstructed. The following will present the AVE values for all variables which can be seen in the following table,

Table 2: Average Variance Extracted (AVE)

\begin{tabular}{|c|c|c|}
\hline Variable & $\begin{array}{c}\text { Initial Average } \\
\text { Variance Extracted } \\
\text { (AVE) }\end{array}$ & $\begin{array}{c}\text { Final Average } \\
\text { Variance Extracted } \\
\text { (AVE) }\end{array}$ \\
\hline Directive leadership style & 0.454 & 0.626 \\
\hline $\begin{array}{c}\text { Participative leadership } \\
\text { style }\end{array}$ & 0.808 & 0.808 \\
\hline $\begin{array}{c}\text { Supportive leadership } \\
\text { style }\end{array}$ & 0.735 & 0.735 \\
\hline Work climate & 0.412 & 0.542 \\
\hline Job satisfaction & 0.482 & 0.516 \\
\hline
\end{tabular}

Reference: Authors

As Table 2 above, it can be seen that in the initial measurement results there are still variables that have an AVE root value below 0.5 , namely the directive leadership style variable, with an initial value of 0.454 and the work climate variable with an initial value of 0.412 and the job satisfaction variable, namely the valueinitially 0.482 . This shows that not all variables in the model meet the discriminant validity criteria, therefore modifications need to 
be made and are expected to meet the criteria. After modification, the results show that all variables have an AVE value above 0.5 so that it can be said that all constructs have met the discriminant validity value or have a good validity value.

\section{c) Reliability Test}

The construct reliability test was measured by 2 criteria, namely composite reliability and Cronbach's alpha. Composite reliability shows internal consistency, namely a high composite reliability value indicates the consistency value of each indicator in measuring the construct. Meanwhile, Cronbach's alpha is a general measure of the consistency of a multi-item scale.

\section{- Evaluating Composite Reliability}

The reliability test is carried out by looking at the composite reliability value of the indicator block that measures the construct. The construct is said to be reliable if the composite reliability value is above 0.7 . The value of composite reliability can be seen in the following table,

Table 3: Composite Reliability (CR)

\begin{tabular}{|c|c|c|}
\hline Variable & $\begin{array}{c}\text { Initial Composite } \\
\text { Reliability (CR) }\end{array}$ & $\begin{array}{c}\text { Final Composite } \\
\text { Reliability (CR) }\end{array}$ \\
\hline Directive leadership style & 0.805 & 0.869 \\
\hline Partisipative leadership style & 0.962 & 0.962 \\
\hline Supportive leadership style & 0.943 & 0.943 \\
\hline Work climate & 0.86 & 0.862 \\
\hline Job satisfaction & 0.925 & 0.931 \\
\hline
\end{tabular}

Table 3 indicated the value of composite reliability which since the beginning of the measurement has met the criteria. However, after modifications were made to several indicators to meet the outer loading at the initial stage of the study, the final results obtained were that all variables still had good reliability and met the criteria for composite reliability values with values above 0.7 .

\section{- Evaluating Cronbach's Alpha}

The reliability test was also strengthened by Cronbach's alpha. The construct is said to be reliable if the value of cronbach's alpha $\geq 0$. The value of cronbach's alpha can be seen in the following table,
Table 4: Cronbach's Alpha

\begin{tabular}{|c|c|c|}
\hline Variable & $\begin{array}{c}\text { Initial Cronbach's } \\
\text { Alpha }\end{array}$ & $\begin{array}{c}\text { Final Cronbach's } \\
\text { Alpha }\end{array}$ \\
\hline Directive leadership style & 0.753 & 0.801 \\
\hline Participative leadership style & 0.952 & 0.952 \\
\hline Supportive leadership style & 0.928 & 0.928 \\
\hline Work climate & 0.818 & 0.817 \\
\hline Job satisfaction & 0.91 & 0.919 \\
\hline
\end{tabular}

According to Table 4, it shows that the measurement of all variables has met the criteria of Cronbach'salpha, both the initial measurement and the end of the measurement have good reliability and meet the criteria of Cronbach's alpha value with a value above 0.5 .

\section{3) Structutral Model Measurement (Inner Model)}

The inner model test was conducted to examine the relationship between the hypothesized exogenous and endogenous constructs. The output of the structural model is done by looking at the value of $\mathrm{R}^{2}$ (coefficient of determination), as shown in the table below.

Table 5: R-Square Value

\begin{tabular}{|c|c|}
\hline Variable & R Square \\
\hline Work climate & 0.631 \\
\hline Job satisfaction & 0.758 \\
\hline
\end{tabular}

This study uses 2 variables that are influenced (dependent) by other (independent) variables, where the work climate and job satisfaction variables are influenced by each variable of directive leadership style, participatory leadership style, and supportive leadership style. Table 5 shows that the RSquare value for the work climate variable is 0.631 . These results indicate that $63.1 \%$ of work climate variables can be influenced by three leadership style variables. Similarly, the variable job satisfaction is influenced by the three leadership styles by 0.758 or $75.8 \%$.

\section{Research Hypothesis}

The basis used in testing the hypothesis proposed in the study is the value contained in the output result for inner weight. The following table provides the estimated output for structural model testing. The significance of the estimated parameters provides very useful information about the relationship between the research variables.

Table 6: Estimated Value of the Effect of Independent Variables on Dependent Variables

\begin{tabular}{|c|c|c|c|}
\hline Path Diagram & $\begin{array}{c}\text { Direct effect ofleadership style---> } \\
\text { Work climate }\end{array}$ & $\begin{array}{c}\text { Indirect effect of leadership style--> } \\
\text { Job satisfaction }\end{array}$ & $\begin{array}{c}\text { Total } \\
\text { effect }\end{array}$ \\
\hline $\begin{array}{c}\text { Directive leadership style--->Work climate } \\
\text { Directive leadership style--->Job satisfaction }\end{array}$ & -0.013 & -0.011 & -0.024 \\
\hline $\begin{array}{c}\text { Participative leadership style->Work climate } \\
\text { Participative leadership style--> Job satisfaction }\end{array}$ & 0.327 & 0.285 & 0.612 \\
\hline $\begin{array}{c}\text { Supportive leadership style->Work climate } \\
\text { Supportive--->Job satisfaction }\end{array}$ & 0.496 & 0.432 & 0.928 \\
\hline Work climate->Job satisfactiojn & 0.871 & & \\
\hline
\end{tabular}

The statistical analysis using PLS test states that each hypothesized relationship is carried out using simulation. In this case, the bootstrap method is applied to the sample. 


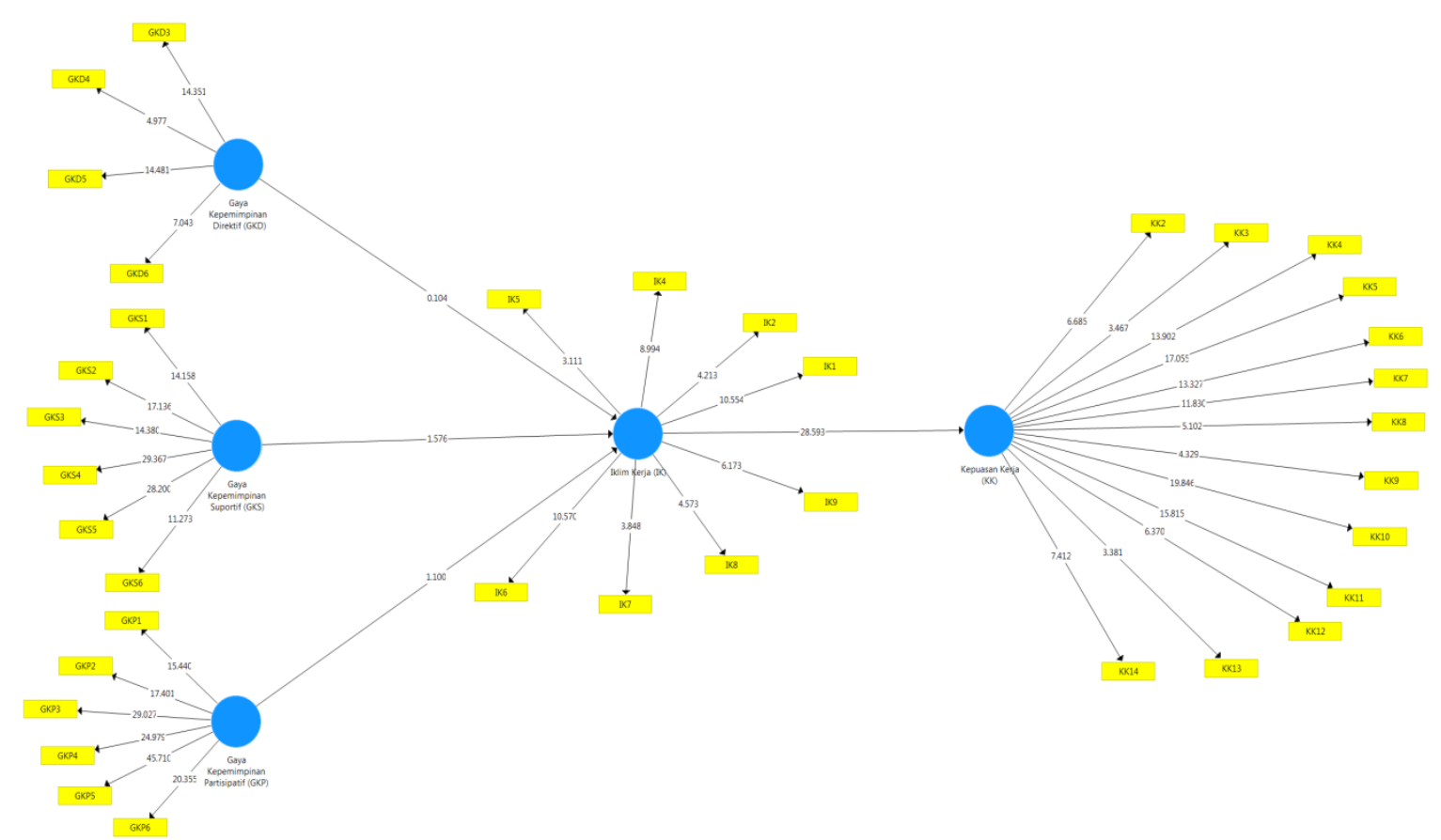

Notes: GKD= directive leadership style (X1)

$\mathrm{GKS}=$ supportive leadership style $(\mathrm{X} 2)$

$\mathrm{GKP}=$ participative leadership style (X3)

$\mathrm{IK}=$ work climate $(\mathrm{Y})$

$\mathrm{KK}=$ work satisfaction $(\mathrm{Z})$

Figure 1: Inner Model resampling bootstrap method.

Testing with bootstrap is also intended to minimize the problem of abnormal research data. The results of the bootstrapping test from the PLS analysis are as follows:

a) Hypothesis Test 1 (directive leadership style $\rightarrow$ work climate)

The results of testing for the first hypothesis indicate that the influence of the directive leadership style variable on the work climate variable shows a path coefficient value of- 0.013 with a t value of 0.104 . This value is smaller than the value of $t$ table (1.96). These results indicate that the directive leadership style has a negative effect on work climate, but it is not significant.

b) Hypothesis Test 2 (Participative leadership style $\rightarrow$ work climate)

The results of testing the second hypothesis indicate that the influence of the participatory leadership style variable on the work climate shows a path coefficient value of 0.327 with a $t$ value of 1.10 . This value is smaller than the value of $t$ table (1.96). These results indicate that the participatory leadership style has a positive effect on the work climate, but it is not significant.

c) Hypothesis Test 3 (supportive leadership style $\rightarrow$ work climate)

The results of the third hypothesis testing show that the supportive leadership style variable has an effect on the work climate, the path coefficient value is 0.496 with a $t$ value of 1.58. This value is smaller than the value of $t$ table (1.96). These results indicate that the supportive leadership style has a positive effect on the work climate, but it is not significant.

d) HypothesisTest 4 (work climate mediation $\rightarrow$ job satisfaction)
The results of the fourth hypothesis testing show the mediating effect of the work climate variable on the job satisfaction variable, showing the path coefficient value of 0.871 with a $t$ value of 28,593 . This value is greater than the value of $t$ table (1.96). These results indicate that the work climate has a positive mediating effect on the job satisfaction variable.

Based on $\mathrm{R}$ Square for the work climate variable, it is obtained $0.631(63.1 \%)$. The number of independent variables $(\mathrm{k})$ is 3 and the number of research samples $(\mathrm{n})$ is 71 with a significance level of of $5 \%$, so the F-count value can be obtained as follows:

$$
\begin{gathered}
\text { Fcount }=\frac{R^{2}(n-k-1)}{\left(1-R^{2}\right) k} \\
=\frac{0.631(71-3-1)}{(1-0.63 l) 3}=60.52 \\
\mathrm{~F}_{\text {table }}=2.83
\end{gathered}
$$

Fcount of $60.52 \geq$ Ftable of 2.83 , this indicates that the leadership style variable simultaneously affects the work climate.

R Square for the job satisfaction variable is 0.758 (75.8\%). The simultaneous influence of leadership style variables on job satisfaction can be calculated using the above formula, the results are as follows,

$$
=\frac{0.758(46-3-1)}{(1-0.758) 3}=69.95
$$


Therefore F count $69.95 \geq F$ table of 2.83 , indicating that the leadership style variable simultaneously affects job satisfaction.

\section{Discussion}

Based on the hypotheses proposed in this study, all of them show evidence that both directive and participative and supportive leadership styles simultaneously affect work climate and job satisfaction. That is, the higher the value of the leadership style, the higher the value of work climate and job satisfaction or in other words, the better the employee's perception of the leadership style, the better the work climate and job satisfaction felt by employees. This can be seen from the results of the $F$ test which shows that simultaneously leadership style has a positive effect on work climate and employee job satisfaction. The results of this study are in line with research conducted by Holloway (2012), which states that leadership behaviors are positively related to the employees' perceptions of organizational climate.

It is necessary to state the results of this study that partially directive leadership style has a negative influence on work climate and job satisfaction. This means that the higher or more intense the application of the directive style will create a less conducive work climate, as well as the decrease in job satisfaction. However, the negative effect is relatively small compared to the positive effect provided by the participatory leadership style and the supportive leadership style.

This study found the fact that participatory and supportive leadership styles gave a positive value to improving organizational climate and employee job satisfaction. Therefore, it becomes a logical reason to state that the most appropriate combination of leadership styles today is a participative and supportive leadership style. In terms of participatory leadership style, the leader conducts a two-way evaluation, namely the leader and subordinates communicate with each other about things that are considered to need improvement, and seek solutions together. Thus, good relations are always maintained, as well as in terms of supervision/control carried out by taking into account the employee's work motivation remains stable. In addition, leadership in a participatory style is expected by employees to develop a work atmosphere that is not boring. Leaders provide solutions to new tasks for employees and provide opportunities to submit complaints in carrying out these new jobs or tasks. Likewise, the supportive leadership style invites subordinates to discuss organizational policies that are relevant to the duties/responsibilities of employees. Employees like to get attention from management when they do a good job. Leaders always cooperate with employees in completing work. Always provide opportunities for employees to discuss work-related issues. Leaders always invite cooperation to facilitate communication between employees in doing work, and intervene to help complete tasks orwork that are not in accordance with the target.

A good working climate as perceived by employees, among others; their work is clearly defined and structured; . employees know clearly who has formal authority to make decisions; employees know the goals to be achieved; mutual trust between employees in the workplace; support from colleagues in completing daily tasks. This study found the fact that work climate affects employee job satisfaction. These results are in line with the results of research conducted by; (Bushra., Usman., Naveed, 2011; Treputtharata \&Tayiam, 2014; Gul et al., 2015; Rahimic, 2013).

Job satisfaction perceived or felt by employees such as; feel comfortable working in the office; feel valued as a human resource; cooperation is established between employees and leaders as well as among fellow employees; leadership tolerance for unintentional mistakes by employees; innovation in getting the job done; . there is a balance between work/office affairs and family affairs that goes very well; can complete the work on time. These indicators strongly support employee job satisfaction.

The conducive work climate at Tadulako University can be linked to the university's policy of rotating or mutating from one work unit to another. This policy was responded well by the employees as a refresher effort, adding insight and experience as well as interaction with fellow employees. However, it should be noted that the time span for making mutations should not be too short to be transferred from one work unit to another. In addition, it is also necessary to adjust the competence of employees in the work unit they will occupy, and the transfer is based on the results of an objective study or analysis from the leadership.

\section{Conclusion}

- Simultaneous leadership style has a positive effect on both the work climate and job satisfaction.

- The directive leadership style partially has a negative influence on the work climate and job satisfaction.

- The participatory and supportive leadership style partially has a positive influence on the work climate and job satisfaction.

- Work climate can mediate the influence of leadership style on job satisfaction.

\section{Suggestion}

- Need to apply a leadership style that is more inclined to a participative and/or supportive leadership style

- Need to increase salary/incentives to meet the standard of living needs of employees

- Opportunities for promotion/career advancement, all employees should have equal opportunities and based on an objective and transparent assessment.

\section{References}

[1] Arora, Nitin., Nuseir, M. T., Falade, T. A., Nusair, T. (2010). Effect Size Measurement Of The MetaAnalytic Influence Of Organizational Climate On Employee Job Satisfaction. Social Responsibility, Professional Ethics, and Management Proceedings of the 11th International Conference. Ankara, Turkey, 24-27 November 2010 
[2] Blanchard, Ken. (2007). A Situational Approach to Managing People. Ignite! Newsletter-May 2007. http: //www. tr.51job. com/kbc/index. php

[3] Bushra, Fatima., Usma, Ahmad., Naveed, Asvir. (2011). Effect of Transformational Leadership on Employees' Job Satisfaction and Organizational Commitment in Banking Sector of Lahore (Pakistan). International Journal of Business and Social Science Vol.2 No.18. www.ijbssnet. com

[4] Flora, Mercy. O. (2019). A theoretical Account of Human Resource Management Practices, Ethical Work Climate and Employee Ethical Behavior: A Critical Literature Review. Business Management Dynamics Vol.9, No.04, Oct 2019, pp.01-08 https: //www.researchgate. net/publication/338711892

[5] Ghozali, Imam (2014). Structural Equation Modeling, Metode Alternatif dengan Partial Least Square (PLS). Edisi 4. Semarang: Badan Penerbit Universitas Diponegoro

[6] Gul, Irum., Faheem, S. H. B., Rizvi, A. (2015). Effect Of Organizational Work Climate On Job Satisfaction: An Empirical Study Of Engro Foods LTD Pakistan. IBT Journal of Business Studies (Formerly Journal of Management \& Social Sciences) Vol.11, No.2, 65-80

[7] Holloway, Joseph B. (2012). Leadership Behavior and Organizational Climate: An Empirical Study in a Nonprofit Organization. Emerging Leadership Journeys, Vol.5 Iss.1, pp.9-35. Regent University School of Global Leadership \& Entrepreneurship ISSN 19414684 editorelj@ regent. edu

[8] Hussein, Ananda Sabil. (2018). Modul Pelatihan Partial Least Squares dengan SmartPLS Untuk Penelitian Manajemen. Palu: Fakultas Ekonomi Universitas Tadulako.

[9] Imran, Rabia., Fatima, Afsheen., Zaheer, Arshad., Yousaf, Imran., Batool, Iram. (2012). How to Boost Employee Performance: Investigating the Influence of Transformational Leadership and Work Environment in a Pakistani Perspective. Middle-East Journal of Scientific esearch 11 (10): 1455-1462, ISSN 19909233. DOI: 10.5829/idosi. mejsr.2012.11.10.741

[10] Javed, Masooma., Balouch, R., \& Hassan, F. (2014). Determinants of Job Satisfaction and its Impact on Employee Performance and Turnover Intentions. International Journal of Learning \& Development ISSN 2164-4063, Vol.4, No.2 http: //dx. doi. org/10.5296/ ijld. v4i2.6094

[11] Omolayo, Bunmi. (2007). "Effect of Leadership Style on Job-Related Tension and Psychological Sense of Community in Work Organizations: A Case Study of Four Organizations in Lagos State, Nigeria. Bangladesh e-Journal Sociology. vol.4, no.2, pp.3037. http: //www.bangladeshsociology. org/Effect of Leadership Style

[12] Perna, Brian. (2016). Exploring Situational Leadership in Quick Service Restaurants. Journal of Business Studiesbb Quarterly, Volume 8, Number2ISSN 2152$1034 . \quad$ https: //www.researchgate. net/publication/333782598

[13] Qaiser, Rizwan D., Draz Umar., Yasir, Hafiz Ali. (2015). Impact of Organizational limate on Job Satisfaction and Organizational Commitment in Education Sector of Pakistan. American Journal of
Mobile Systems, Applications and Services. Vol.1, No.2, 2015, pp.102-109. http: //www.aiscience. org/journal/ajmsas

[14] Rahimic, Zijada. (2013). Influence of Organizational Climate on Job Satisfaction in Bosnia and Herzegovina Companies. International Business Research; Vol.6, No. ISSN 1913-9004 E-ISSN 1913-9012. Published by Canadian Center of Science and Education. http: //dx. doi. org/10.5539/ibr. v6n3p129

[15] Treputtharat, Saowanee and Tayiam, S. (2014). School Climate Affecting Job Satisfaction of Teachers in Primary Education, Khon Kaen, Thailand. ProcediaSocial Behaviour Science., vol.116, pp.996-1000. doi: 10.1016/j. sbspro.2014.01.334.

[16] Yamin, Sofyan \& Kurniawan, Heri. (2009). Structural Equation Modelling. Jakarta: Salemba EmpatUse the "Insert Citation" button to add citations to this document. 